\title{
Destimulativan zakonski okvir kao uzrok neuspjeha sustava dobrovoljnog mirovinskog osiguranja: studija crnogorskog slučaja kao pokazatelj važnosti financijskih poticaja
}

\author{
VLADIMIR SAVKOVIĆ* \\ NIKOLA DOŽIĆ \\ Pravni fakultet \\ Univerzitet Crne Gore \\ Podgorica, Crna Gora
}

\author{
Pregledni znanstveni rad \\ doi: $10.3935 /$ rsp.v25i3.1486 \\ UDK: 368.914(497.16) \\ Primljeno: srpanj 2017.
}

Predstavljeno istraživanje ima dva usko povezana cilja. Prvi, pokazati da je destimulativan zakonski okvir $i$ u tom kontekstu izostanak financijskih poticaja članovima primarni uzrok neuspjeha dobrovoljnog mirovinskog osiguranja u Crnoj Gori. Drugi, da se u granicama postavljenog metodološkog okvira potvrdi da financijski poticaji predstavljaju jedan od bitnih faktora utjecaja na uspjeh sustava dobrovoljnog mirovinskog osiguranja. Istraživanje je postavljeno na način da iskoristi dvije ključne okolnosti: da Crna Gora predstavlja vrlo rijedak primjer zemlje u kojoj ne postoje financijski poticaji članovima, te da su pokazatelji ostalih ključnih faktora utjecaja na uspjeh dobrovoljnih mirovinskih fondova u Crnoj Gori i zemljama bivše Jugoslavije koje su predmet poredbene analize približno istih vrijednosti. Zahvaljujući tomu, autori su istraživanjem uspjeli izdvojiti snažno negativno djelovanje izostanka financijskih poticaja na poslovanje dobrovoljnih mirovinskih fondova u Crnoj Gori. Time su u bitnome potvrđene početne hipoteze o uzroku neuspjeha crnogorskog sustava, te značaju financijskih poticaja za razvoj dobrovoljnog mirovinskog osiguranja.

Ključne riječi: dobrovoljno mirovinsko osiguranje, financijski poticaji, zakonski okvir, ključni faktori utjecaja, Crna Gora, zemlje bivše Jugoslavije.

${ }^{*}$ Vladimir Savković, Pravni fakultet Univerziteta Crne Gore / University of Montenegro, Faculty of Law, 13. Jula br. 2, 81000 Podgorica, Crna Gora/Montenegro, vsavkovic@t-com.me 


\section{UVOD}

\section{Dobrovoljni mirovinski fondovi u 21 . stoljeću}

Iako se njihove preteče javljaju još krajem 19. stoljeća, te kontinuirano i na različitim meridijanima razvijaju tijekom čitavog narednog, ${ }^{1}$ dinamika promjena kojoj su suvremeni nacionalni sustavi mirovinskog osiguranja izloženi početkom 21 . stoljeća je bez presedana. Razlozi su brojni. Ipak, ističu se sve kraći ciklusi globalnih i regionalnih ekonomskih kriza, ekstremni demografski trendovi, ubrzano starenje stanovništva upravo u zemljama koje su nositelji povijesnog razvoja i komercijalizacije mirovinskih sustava, kao i snažni poticaji u vidu prijedloga reformi i preferiranih modela od strane međunarodnih organizacija koje simboliziraju globalne centre moći, posebno Svjetske banke. ${ }^{2}$ Pored toga, uloga mirovinskog osiguranja i mirovinskih fondova odavno se više ne svodi na tradicionalne funkcije, prevenciju siromaštva $u$ starosti i nakon gubitka radne sposobnosti, odnosno osiguranje iste ili slične razine životnog standarda osiguranika do kraja životnog vijeka (Blake, 2006.: 145). Naime, mirovinski fondovi danas su redovno značajni institucionalni investitori na tržištima vrijednosnih papira i financijskim tr- žištima uopće, snažno utječući na njihovu stabilnost i ukupne performanse nacionalnih ekonomija. Sve to potiče zanimanje na nacionalnom i međunarodnom planu za dodatno reguliranje rada mirovinskih fondova i trgovačkih društava koja njima upravljaju, što u krajnjem rezultira još intenzivnijom dinamikom izmjena njihovih strukturnih i operativnih obrazaca.

U kontekstu iznesenog, s pravom se može govoriti ne samo o aktualnom, već i o velikom potencijalnom značaju dobrovoljnih mirovinskih fondova. Naime, suština koncepta na kojem su zasnovani - slobodan pristup za sve zainteresirane, te gotovo neograničena fleksibilnost u pogledu visine i dinamike ulaganja novčanih sredstava $u$ njih - čini da upravo ova vrsta mirovinskih fondova ima najveći prostor za rast broja članova i vrijednosti portfolija kojima upravljaju. Na regionalnom planu, na prostoru istočne i jugoistočne Europe, takav je dojam još uvjerljiviji uslijed okolnosti da su procesi uvođenja trećeg stupa mirovinskog osiguranja počeli tek u posljednjem desetljeću 20. stoljeća. Štoviše, u zemljama bivše Jugoslavije, osim Bosne i Hercegovine, u kojoj su tek u fazi osnivanja, te Slovenije koja je u zakonsku reformu krenula nešto ranije, ${ }^{3}$ dobrovoljni mirovinski fondovi uvedeni su tek početkom 21 . stoljeća. ${ }^{4}$

\footnotetext{
${ }^{1}$ Ilustracije radi, jedan od prvih i najčešće analiziranih prethodnika cjelovitih nacionalnih sustava mirovinskog osiguranja zasnovanih na međugeneracijskoj solidarnosti (tzv. »prvi stup« mirovinskog osiguranja) nastaje kao rezultat reformi njemačkog kancelara Bismarcka, u drugoj polovici 19. stoljeća. Na drugoj strani, u SAD-u i nekim europskim državama krajem 19. i početkom 20. stoljeća razvijali su se prethodnici današnjih kapitalno financiranih mirovinskih sustava - drugi i treći stup mirovinskog osiguranja (Verbon, 1988.: 16-30).

${ }^{2}$ Upravo je Svjetska banka, kao neformalni lider na ovom planu, razradila i globalno promovirala sada široko prihvaćeni koncept tri stupa mirovinskog osiguranja (World Bank, 1994.), koji je kasnije, 2005. godine, nadogradila uvođenjem ideje o postojanju nultog i četvrtog stupa (oWorld Bank, 2005.). Značajnu ulogu na globalnom, odnosno planu regionalnog razvoja i reguliranja dobrovoljnih mirovinskih fondova ima i OECD (Organization for Economic Cooperation and Develompent) preko utjecajnih strateških analiza i Europska unija preko konkretnih regulatornih instrumenata.

${ }^{3}$ U Sloveniji je mogućnost dobrovoljnog mirovinskog osiguranja uvedena zakonskom reformom 1999. godine i dostupna je kroz različite mirovinske sheme (Majcen i Verbič, 2009.).

${ }^{4}$ Zakonska reforma kojom su uvedeni dobrovoljni mirovinski fondovi u nacionalni sustav mirovinskog osiguranja u Hrvatskoj je provedena 2002. godine, a u Srbiji 2005. godine (Guardiancich, 2010.). U Crnoj Gori je zakonska osnova za dobrovoljne mirovinske fondove stvorena 2006. godine (Vlada Crne Gore, 2013.), dok je u Makedoniji treći stup mirovinskog osiguranja uveden 2008. godine (Bornarova et al., 2013.: 395).
} 
Značaj dobrovoljnih mirovinskih fondova i njihovog uspješnog poslovanja na financijskim tržištima posebno je naglašen i okolnošću da isti osiguravaju dodatnu diversifikaciju rizika koji redovno prijete nacionalnim mirovinskim sustavima, jačajući time njihovu otpornost na negativne društvene trendove. Pored toga, ovi fondovi osiguravaju pristup sustavima mirovinskog osiguranja i njima svojstvenim beneficijama onim kategorijama potencijalnih osiguranika koje nisu obuhvaćene prvim i drugim stupom, poput osoba koje nisu uopće u radnom odnosu ili nisu uposlene kod poslodavaca uključenih u drugi stup mirovinskog osiguranja (Chen i Beetsma, 2015.). Stoga, nadovezujući se na stajalište kako su najuspješniji nacionalni sustavi oni koji imaju skladne i prema specifičnim potrebama društva uklopljene sve stupove mirovinskog osiguranja (World Bank, 2005.: 172), možemo zaključiti kako je upravo funkcionalan sustav dobrovoljnih mirovinskih fondova zasnovan na individualnoj kapitaliziranoj štednji, tj. razvijen treći stup mirovinskog osiguranja, po pravilu, dobar pokazatelj takvog uspjeha.

Istaknuta okolnost daje dodatni značaj istraživanju predstavljenom u ovom radu. Naime, predmet istog su upravo dobrovoljni mirovinski fondovi, odnosno specifičan faktor utjecaja na njihovo poslovanje, čiji izrazit značaj u tom smislu autori dokazuju u ovom radu.

\section{Cilj istraživanja}

Cilj ovog rada i istraživanja predstavljenog u njemu jest da se prikupljanjem, znanstvenom obradom, te poredbenom $\mathrm{i}$ drugom analizom relevantnih parametara sustava dobrovoljnih mirovinskih fondova u Crnoj Gori i odabranim državama bivše Jugoslavije u bitnome potvrde dva povezana zaključka. Prvi, da je destimulativan zakonski okvir i u tom kontekstu potpuni izostanak financijskih poticaja za potencijalne ulagače, $\mathrm{tj}$. članove osnovni razlog neuspjeha sustava dobrovoljnih mirovinskih fondova u Crnoj Gori u prethodnom desetljeću, tj. izrazito malog broja članova dobrovoljnih mirovinskih fondova. Drugi, da su upravo financijski poticaji ulagačima jedan od ključnih faktora utjecaja na uspjeh dobrovoljnih mirovinskih fondova, odnosno trećeg stupa mirovinskog osiguranja.

\section{Metodološki okvir i tijek istraživanja}

Izostanak zakonom zajamčenih financijskih poticaja građanima da ulažu u dobrovoljne mirovinske fondove, bilo da je riječ o poreznim olakšicama, državnim doprinosima ili nekom drugom obliku stimulansa, predstavlja rijetku karakteristiku trećeg stupa mirovinskog osiguranja u $\mathrm{Cr}$ noj Gori. Ista izdvaja crnogorski od ostalih suvremenih sustava dobrovoljnog mirovinskog osiguranja, kod kojih je neka forma financijskog (državnog) stimulansa unaprijed zajamčena ulagačima. ${ }^{5}$ Međutim, upravo zato je crnogorski slučaj posebno vrijedan predmet istraživanja i značajan uzorak za empirijsku provjeru jačine utjecaja koji izostanak državnih poticaja ima na uspješnost sustava dobrovoljnih mirovinskih fondova. Naime, najveći broj istraživanja ovog fenomena i uopće utjecaja financijskih stimulansa na alokaciju raspoloživih sredstava pojedinca i domaćinstava rađen je u SAD-u, gdje su prvi oblici poreznih olakšica za ula-

\footnotetext{
${ }^{5}$ Pored crnogorskog, autorima nije poznat primjer još nekog suvremenog i funkcionalno zaokruženeg sustava dobrovoljnog mirovinskog osiguranja u kojem ulaganje na neki način nije i formalno stimulirano od strane države. Međutim, ukoliko takav sustav mirovinskog osiguranja i postoji, crnogorski primjer je izvjesno dovoljno rijedak i jedinstven u smislu usporedivosti sa svojim regionalnim pandanima da se njegova vrijednost kao predmeta istraživanja i analize $u$ danom kontekstu ne dovodi u pitanje.
} 
ganje u mirovinske fondove uvedeni još u prvoj polovici 20. stoljeća (Jansson, 2005.: 406). Međutim, autori koji su analizirali rezultate tih istraživanja, kao jedan od ključnih problema $u$ pogledu njihove relevantnosti, ističu upravo problem pronalaženja odgovarajućeg uzorka - dvije grupe ljudi koje su istovremeno pod približno jednakim utjecajem svih relevantnih faktora, osim onog koji je predmet istraživanja (Barnheim, 2001.: 1214). U tom kontekstu, posebna vrijednost ovdje predstavljenog istraživanja financijskih stimulansa kao faktora utjecaja na uspjeh nacionalnih sustava dobrovoljnih mirovinskih fondova jest da su takve poteškoće, odnosno problemi u najvećoj mjeri izbjegnuti. Razlog tome je upravo istaknuta specifičnost zakonskog okvira crnogorskog sustava dobrovoljnih mirovinskih fondova, na jednoj strani, ali i ujednačen utjecaj koji ostali ključni faktori imaju na uspješnost crnogorskog i ostalih s njim uspoređenih nacionalnih sustava bivše Jugoslavije, što autori istraživanjem i demonstriraju, na drugoj strani.

Pored navedenog, istraživanju na praktičnom značaju posebno daje i to što se bavi pitanjem koje je još uvijek vrlo otvoreno u praksi i relevantnim studijama. Naime, bez obzira na to što se ne dovodi u pitanje generalno pozitivan utjecaj financijskih stimulansa, dvojbe itekako postoje oko njihovog značaja, tj. jačine utjecaja. Primjera radi, u studiji o nacionalnim mirovinskim sustavima država članica, pripremljenoj za potrebe Europskog parlamenta, upravo se ističe da još uvijek nije jasno u kojoj mjeri stimulansi za dodatnu štednju u sklopu trećeg stupa mirovinskog osiguranja vode povećanju takvih izdvajanja (General Secretariat of the European Parliament, 2014.: 38). U nekim drugim radovima, pak, problematizira se i suštinski osporava stav o ključnom značaju i učinkovitosti financijskih stimulansa u formi poreznih olakšica za ulaganje u mirovinske fondove (Bosi i Guerra, 2002.). Konačno, između ostalih, svjedoci smo i studija u kojima se primarni značaj financijskih državnih stimulansa na promatrani rast broja ulagača u dobrovoljne mirovinske fondove pretpostavlja, ali bez dubljih analiza koje bi prethodile takvom zaključku (Rocha i Vittas, 2002.: 393.).

Na drugoj strani, pak, treba istaknuti i postojanje studija, tj. istraživanja, istina, na nacionalnom planu, koja ukazuju na jasnu korelaciju između financijskih poticaja i slobodne odluke pojedinaca ili njihovih poslodavaca da ulažu u dobrovoljne mirovinske fondove (Börsch-Supan et al., 2007.; Paiella i Tiseno, 2014.). No, imajući izneseno u vidu, smatramo da to svakako ne umanjuje aktualnost ovdje predstavljenog istraživanja.

Sukladno tome da je za primarni kriterij uspješnosti poslovanja sustava dobrovoljnih mirovinskih fondova uzet ukupan broj članova, ${ }^{6}$ istraživanje je započeto upravo prikupljanjem podataka i poredbenom analizom broja ulagača u dobrovoljne mirovinske fondove u Crnoj Gori i u državama bivše Jugoslavije čiji su sustavi dobrovoljnog mirovinskog osiguranja izravno usporedivi sa crnogorskim - Hrvatskoj, Srbiji i Makedoniji. $^{7}$ Ova analiza, prikazana u drugom dijelu rada, pokazuje da, razmjerno broju

${ }^{6}$ Više o ovom i dodatnim kriterijima u narednom dijelu rada.

7 Već je istaknuto da u Bosni i Hercegovini ovaj sustav de facto ne postoji, dok je u Sloveniji dobrovoljno mirovinsko osiguranje uvedeno još 1999. godine, što je, primjera radi, gotovo deset godina ranije nego u Makedoniji. Pored toga, Slovenija nije ni izbliza toliko dugo i snažno bila pod utjecajem posljedica raspada zajedničke države kao ostale bivše jugoslovenske republike, uslijed čega nije prolazila kroz političke, ekonomske i druge procese karakteristične za ostale zemlje bivše Jugoslavije. Tako je Slovenija postala članicom Europske unije u trenutku kada je dobrovoljno mirovinsko osiguranje tek uvedeno ili su za to vršene pripreme u promatranim zemljama. Konačno, i njen sustav dobrovoljnog mirovinskog osiguranja u bitnom je drugačije koncipiran od ostalih u regiji (Guardiancich, 2010; Majcen i Verbič, 2009.). 
stanovnika, treći stup mirovinskog osiguranja u Crnoj Gori bilježi značajno manji broj osiguranika, tj. članova. Time je, uz poredbenu analizu vrijednosti imovine ovih fondova u odnosu na bruto društveni proizvod, koja je očekivano pokazala slične tendencije, pokazano kako je crnogorski sustav dobrovoljnih mirovinskih fondova postigao znatno lošije rezultate u odnosu na usporedno promatrane sustave, a u približno istom razdoblju trajanja. ${ }^{8}$

U nastavku istraživanja, predstavljenom u trećem dijelu rada, predmet poredbene analize na razini Crne Gore i odabranih država bivše Jugoslavije bili su prvo ključni socio-ekonomski faktori utjecaja na uspjeh dobrovoljnih mirovinskih fondova, a potom i pravno-politički, prije svih, zakonski okvir kao svojevrsni sublimat pravno-političkih faktora. Cilj ovih, za rad središnjih analiza, bio je da se metodom eliminacije ujednačenih izdvoje upravo oni pokazatelji promatranih faktora utjecaja koji ukazuju na postojanje bitnih razlika između Crne Gore i drugih država regije, te da se isti dodatno analiziraju radi objektivnog određivanja uzroka ustanovljenog neuspjeha dobrovoljnih mirovinskih fondova u Crnoj Gori.

U dijelu rada u kojem je predstavljena usporedna analiza ključnih socio-ekonomskih faktora, dani su i izvorni podaci u pogledu lokalne raspoređenosti članova crnogorskih fondova dobrovoljnog mirovinskog osiguranja, do kojih su autori došli u suradnji s nacionalnim fondovima i Komisijom za vrijednosne papire. Isti su analizirani u odnosu na autorima i javnosti jedino dostupne, također lokalne statističke pokazatelje ključnih socio-ekonomskih faktora utjecaja na uspješnost poslovanja dobrovoljnih mirovinskih fondova, čime je potvrđeno da se i na toj razini može uočiti određena korelacija između ovih faktora i odluke pojedinca da uloži svoja sredstva. Time je dodatno potvrđena metodološka opravdanost i znanstvena relevantnost prethodno napravljene poredbene analize utjecaja ključnih socio-ekonomskih faktora u zemljama regije.

Naposlijetku, u četvrtom dijelu rada sažeti su najbitniji zaključci u kontekstu postavljenih ciljeva i dane su preporuke.

\section{PRIKAZ USPJEŠNOSTI SUSTAVA DOBROVOLJNOG MIROVINSKOG OSIGURANJA U CRNOJ GORI I NA REGIONALNOM PLANU}

Već je u uvodnom dijelu naznačeno da je za potrebe predmetnog istraživanja kao ključni kriterij uspješnosti nacionalnog sustava dobrovoljnog mirovinskog osiguranja uzet ukupan broj članova. Naime, sa stajališta najširih društvenih interesa i potrebe uspostavljanja funkcionalnog, izbalansiranog, te nacionalnog mirovinskog sustava otpornog na negativne trendove, postojanje ili izostanak relativno široke baze članova trećeg stupa mirovinskog osiguranja najbolji je indikator uspjeha. Stoga su u tablici 1. dani upravo statistički pokazatelji ukupnog broja ulagača $\mathrm{u}$ dobrovoljne mirovinske fondove u Crnoj Gori i u drugim zemljama bivše Jugoslavije čiji su sustavi dobrovoljnog mirovinskog osiguranja, kako je već istaknuto, usporedivi sa crnogorskim.

\footnotetext{
${ }^{8}$ V. supra pn. 4.
} 
Tablica 1.

Usporedni prikaz ukupnog broja ulagača u dobrovoljne mirovinske fondove

\begin{tabular}{lccc}
\hline \multicolumn{1}{c}{ Država } & Broj ulagača (2015.) & Broj stanovnika (2015.) & $\begin{array}{c}\text { Omjer broja osiguranika i } \\
\text { broja stanovnika (\%) }\end{array}$ \\
\hline Crna Gora & $2404^{9}$ & $622218^{13}$ & $0,38 \%$ \\
\hline Hrvatska & $265724^{10}$ & $41906691^{4}$ & $6,47 \%$ \\
\hline Srbija & $190500^{11}$ & $7076372^{15}$ & $2,69 \%$ \\
\hline Makedonija & $21744^{12}$ & $2070226^{16}$ & $1,05 \%$ \\
\hline
\end{tabular}

Pored broja ulagača, u kontekstu gore navedenih društvenih interesa, relevantan indikator može predstavljati i vrijednost uloženih sredstava, odnosno imovine koju dobrovoljni mirovinski fondovi u promatranim državama kontroliraju i postotak koji ta imovina predstavlja u odnosu na bruto društveni proizvod promatrane dr- žave. Istina, ovi podaci u priličnoj mjeri predstavljaju refleksiju statističkih pokazatelja primarno potenciranog kriterija, ali se na osnovi njih ipak može dobiti još jasnija slika o razvijenosti sustava dobrovoljnog mirovinskog osiguranja. Stoga su isti dani u tablici 2.

Tablica 2.

Usporedni prikaz vrijednosti neto imovine fondova

\begin{tabular}{cccc}
\hline Država & $\begin{array}{c}\text { Neto imovina fondo- } \\
\text { va (2015.) }\end{array}$ & $\begin{array}{c}\text { BDP (2015.) } \\
\text { (Bruto društveni proizvod) }\end{array}$ & $\begin{array}{c}\text { Neto imovina } \\
\text { fondova / BDP (\%) }\end{array}$ \\
\hline Crna Gora & $564553^{18}$ & 3624700000 & $0,015 \%$ \\
\hline Hrvatska & $501597713^{19}$ & 43846900000 & $1,14 \%$ \\
\hline Srbija & $234539723^{20}$ & 33491000000 & $0,7 \%$ \\
\hline Makedonija & $11951223^{21}$ & 9060700000 & $1,31 \%$ \\
\hline
\end{tabular}

\footnotetext{
${ }^{9} \mathrm{KHOV}, 2015 .: 43$.

${ }^{10}$ Monstat Procjene stanovništva - Podaci, 2017.

${ }^{11}$ HANFA, 2015.: 71.

${ }^{12}$ Državni zavod za statistiku Hrvatske, 2017.

${ }^{13}$ NBS - Narodna banka Srbije, 2015.: 11.

${ }^{14}$ Republički zavod za statistiku Srbije, 2011.

${ }^{15}$ MAPAS, 2015.: 19.

${ }^{16}$ MAKSTAT - Državni zavod za statistiku Republike Makedonije, 2017.

${ }^{17}$ Za prezentirane podatake za Hrvatsku, Srbiju i Makedoniju, v. Eurostat, Gross domestic product at market prices, 2017. Za prezentirane podatake za Crnu Goru, v. Monstat, 2016.: 66. Metodologija MONSTAT-a usklađena je s metodologijom Eurostata.

${ }^{18} \mathrm{KHOV}, 2015 .: 43$.

${ }^{19}$ HANFA, 2015.: 71. Originalni podaci iskazani su u kunama - 3726053 000, pa je konverzija izvršena prema tečaju 1 HRK = 0,134619 EUR (16. svibnja 2017.).

${ }^{20}$ NBS, 2015.3. Originalni podaci su iskazani u dinarima - 28900000000 , pa je konverzija izvršena prema tečaju 1 RSD = 0,00811556 EUR (16. svibnja 2017.).

${ }^{21}$ MAPAS, 2015.: 23). Originalni podaci su iskazani u denarima - 736000000 , pa je konverzija izvršena prema tečaju $1 \mathrm{MKD}=0,0162381$ EUR (16. svibnja 2017.).
} 
Podaci uspoređeni u tablicama 1. i 2. pokazuju slične tendencije u pogledu razine razvijenosti sustava dobrovoljnog mirovinskog osiguranja u Crnoj Gori i Hrvatskoj. Odatle isti jasno ukazuju na to da je, bez obzira na manje razlike u pogledu dužine trajanja trećeg stupa mirovinskog osiguranja u promatranim državama, ovaj sustav u Crnoj Gori drastično manje razvijen u odnosu na ostale države regije s kojima je uspoređen. Prije svega, na tu okolnost ukazuje postotak koji broj članova dobrovoljnih mirovinskih fondova predstavlja $u$ odnosu na ukupan broj stanovnika u ovim državama. Tako, kada je Crna Gora u pitanju, ovaj postotak je od tri do 17 puta manji od usporedno promatranih. Pored toga, na neuspjeh dobrovoljnih mirovinskih fondova u Crnoj Gori jasno ukazuje i dodatni pokazatelj - postotak koji vrijednost imovine pod kontrolom tih fondova predstavlja $\mathrm{u}$ odnosu na bruto društveni proizvod promatranih nacionalnih ekonomija. Štoviše, ovdje su razlike još drastičnije, pa su postotci dobiveni za Crnu Goru od 46 do 87 puta manji od usporedno promatranih.

Svakako, sama okolnost da između postotaka prikazanih u tablicama 1. i 2. ne postoji apsolutna ili približno takva podudarnost nikako nije pokazatelj irelevantnosti i izostanka indikativnosti danih podataka. Naime, kako je već istaknuto, u oba slučaja se primjećuju slične tendencije, a određena odstupanja mogu se objasniti i razlikama u proizvodu po glavi stanovnika, pa i razlikama u razini samih financijskih poticaja. ${ }^{22}$ Stoga i analizirani podaci, pojedinačno i u korelaciji, predstavljaju dovoljnu potporu ovdje iznesenom zaključku o evidentnom neuspjehu crnogorskog sustava dobrovoljnih mirovinskih fondova u prvom desetljeću njegovog postojanja. Odatle su predmet analize u daljnjem tekstu upravo pokazate- lji ključnih faktora koji mogu predstavljati uzroke takvog neuspjeha.

\section{UZROCI NEUSPJEHA DOBROVOLJNIH MIROVINSKIH FONDOVA U CRNOJ GORI - POREDBENA ANALIZA POKAZATELJA KLJUČNIH FAKTORA UTJECAJA}

\section{Općenito}

Faktori koji mogu utjecati na odluku pojedinca da postane osiguranik i time na uspješnost sustava dobrovoljnog mirovinskog osiguranja različiti su i brojni. No, nisu svi i jednako značajni. Stoga su, istražujući razloge neuspjeha trećeg stupa mirovinskog osiguranja u Crnoj Gori, autori pošli od onih ključnih, čiji je opredjeljujući utjecaj u tom smislu već potvrđen relevantnim i aktualnim istraživanjima. Međutim, prethodno je potrebno podvući da cilj autora nije - niti je to u ovom radu mogao biti - da izvrše provjeru, odnosno stupnjevanje spomenutih faktora prema percipiranom značaju ili utvrđuju opravdanost takvih stupnjevanja u ranijim istraživanjima. To bi, naime, podrazumijevalo temeljnu reviziju polazišta i stavova iznesenih u spomenutim istraživanjima, te znatno obimniju studiju, odnosno rad od ovog. Stoga, kako je već istaknuto, cilj je bio da se na razini promatranih država bivše Jugoslavije usporede službeni statistički pokazatelji upravo onih faktora utjecaja koji su u odgovarajućoj znanstvenoj literaturi potvrđeni kao ključni u smislu usvojenog kriterija uspješnosti dobrovoljnih mirovinskih fondova - broja članova. Nakon toga, cilj je bio da se utvrdi postoje li uopće i kod kojih od iznesenih crnogorskih parametara odstupanja od regionalnog prosjeka, dovoljno izražena da se u pravcu njihove du-

\footnotetext{
${ }^{22}$ Primjerice, u Makedoniji su maksimalni iznosi poticaja osobito visoki. V. infra tablica 5.
} 
blje analize usmjere napori na utvrđivanju uzroka neuspjeha trećeg stupa mirovinskog osiguranja u Crnoj Gori.

\section{Poredbena analiza pokazatelja ključnih socio-ekonomskih faktora utjecaja na uspjeh sustava dobrovoljnog mirovinskog osiguranja}

Izuzimajući zakonski okvir, odnosno zajamčene financijske poticaje, u kontekstu važećih standarda istraživanja u društvenim znanostima, praktično svi faktori utjecaja na uspješno poslovanje dobrovoljnih mirovinskih fondova koji se u literaturi redovno ističu kao ključni mogu se podvesti pod kategoriju socio-ekonomskih. Da- kle, prema istraživanjima predstavljenim u znanstvenoj literaturi (Sane i Thomas, 2015.; Adzawla et al., 2015.; Pfarr i Schneider, 2013.; Collins-Sowah et al., 2013.; Fuentes Corripio, 2010.; Castel, 2008.), na širinu baze članova dobrovoljnih mirovinskih fondova u određenoj sredini bitno utječu faktori kao što su visina prihoda i kupovna moć potencijalnih osiguranika, ekonomska pismenost i razina obrazovanja uopće, razina zaposlenosti radno sposobnog stanovništva, starost stanovništva, bračni status, odnosno učestalost brakova, kao i veličina domaćinstva. Relevantni, tj. službeni statistički pokazatelji ovih faktora utjecaja u Crnoj Gori i promatranim državama bivše Jugoslavije dani su u tablici 3.

Tablica 3.

Usporedni prikaz pokazatelja socio-ekonomskih faktora utjecaja

\begin{tabular}{lcccc}
\hline \multicolumn{1}{c}{ Socio-ekonomski faktor utjecaja } & Hrvatska & Srbija & Makedonija & Crna Gora \\
\hline Prosječna neto zarada u eurima (2015.) & $768,80^{23}$ & $360,59^{24}$ & $356^{25}$ & $480^{26}$ \\
\hline $\begin{array}{l}\text { Bruto društveni proizvod po glavi stanov- } \\
\text { nika u međunarodnim dolarima (Int\$), } \\
\text { prema standardu kupovne moći (2015.) }\end{array}$ & 21881 & 13721 & 13908 & 15464 \\
\hline Stopa nezaposlenosti (2015.) & $16,3^{28}$ & $17,7^{29}$ & $26,1^{30}$ & $17,6^{31}$ \\
\hline $\begin{array}{l}\text { Postotak visokoobrazovanog stanovniš- } \\
\text { tva }\end{array}$ & $16,4^{33}$ & $16,24^{34}$ & $9,98^{35}$ & $13,86^{36}$ \\
\hline $\begin{array}{l}\text { Postotak stanovništva starijeg od 65 godi- } \\
\text { na (2015.) }\end{array}$ & 18,8 & 18,5 & 12,7 & 13,7 \\
\hline Prosječna starost stanovnika & $42,6^{38}$ & $42,7^{39}$ & $38,5^{40}$ & $37,7^{41}$ \\
\hline Veličina domaćinstva & $2,8^{42}$ & $2,9^{43}$ & $3,58^{44}$ & $3,2^{45}$ \\
\hline Broj brakova na 1 000 stanovnika (2015.) & $4,7^{46}$ & $5,2^{47}$ & $6,49^{48}$ & $6,2^{49}$ \\
\hline
\end{tabular}

${ }^{23}$ Državni zavod za statistiku Hrvatske, Statistički ljetopis, 2016.: 174. Originalni podaci iskazani su u kunama - 5,711, pa je konverzija izvršena prema tečaju 1 HRK = 0,134619 EUR (16. svibnja 2017.).

${ }^{24}$ Republički zavod za statistiku Srbije, 2017.: 74. Originalni podaci iskazani su u dinarima - 44,432 pa je konverzija izvršena prema kursu 1 RSD $=0,00811556$ EUR (16. svibnja 2017.).

${ }^{25}$ MAKSTAT Statistički godišnjak, 2017.: 291. Originalni podaci iskazani su u denarima - 21,906 pa je konverzija izvršena prema tečaju $1 \mathrm{MKD}=0,0162381$ EUR (16.5 svibnja 2017.).

${ }^{26}$ Monstat, 2016.60.

${ }^{27}$ Eurostat, Purchasing power parities (PPPs), 2017.

${ }^{28}$ Državni zavod za statistiku Hrvatske, Statistički ljetopis, 2016.: 165.

${ }^{29}$ Republički zavod za statistiku Srbije, Statistički godišnjak, 2017.: 40. 
Podaci izneseni u tablici 3. jasno ukazuju da crnogorski statistički pokazatelji ključnih socio-ekonomskih faktora utjecaja na uspješnost dobrovoljnih mirovinskih fondova ne odstupaju značajnije od statističkih prosjeka grupe zemalja s kojima je usporedba izvršena. Drugim riječima, crnogorski parametri su češće od odgovarajućih parametara ostalih država najbliži srednjoj vrijednosti pojedinih statističkih kategorija koje su bile predmetom istraživanja i analize. Štoviše, niti jedan od crnogorskih pokazatelja relevantnih socio-ekonomskih faktora utjecaja na uspješnost dobrovoljnih mirovinskih fondova nije na početku ili na začelju u analiziranim statističkim kategorijama, osim onog u pogledu prosječne starosti stanovnika. No, nesporno je kako okolnost da je crnogorsko stanovništvo tek nešto mlađe od stanovništva usporedno promatranih država ne može predstavljati dovoljnu osnovu za zaključak da ovaj socio-ekonomski faktor presudno utječe na drastično različit uspjeh crnogorskog u odnosu na analizirane regionalne sustave dobrovoljnog mirovinskog osiguranja.

Dakle, imajući izneseno u vidu, možemo zaključiti da analiza statističkih vrijednosti iskazanih u tablici 3. ukazuje na opravdanost sljedećeg zaključka. Ključni socio-ekonomski faktori u Crnoj Gori nemaju specifičan utjecaj, tj. ne djeluju bitno drugačijim intenzitetom kojim bi se eventualno mogao objasniti izrazit neuspjeh crnogorskih fondova dobrovoljnog mirovinskog osiguranja.

Kao dodatnu potvrdu ispravnosti metodološkog pristupa kojim se došlo do gore iznesenog zaključka, imajući u vidu ograničenja u pogledu obujma rada, ali i dostupnosti podataka, na ovom mjestu iznosimo i primjer utjecaja na lokalnoj razini dvaju iz grupe ključnih socio-ekonomskih faktora danih u tablici 3. Riječ je o stopama nezaposlenosti i obrazovanja stanovništva u tri regije na koje se Crna Gora dijeli za

\footnotetext{
${ }^{30}$ MAKSTAT Statistički godišnjak, 2017.: 63.

${ }^{31}$ Monstat, 2016.54.

${ }^{32}$ Postotak visokoobrazovanih stanovnika u promatranim zemljama prikazan je kao odnos broja stanovnika prema posljednjem popisu stanovništva i broja visokoobrazovanih osoba.

${ }^{33}$ Podaci su dani prema popisu stanovništva Hrvatske iz 2011. (Državni zavod za statistiku Hrvatske, Statistički ljetopis, 2016.: 13).

${ }^{34}$ Podaci su izvedeni prema popisu stanovništva Srbije iz 2011. (Republički zavod za statistiku Srbije, Statistički kalendar Republike Srbije, 2016.: 34).

${ }^{35}$ Podaci su navedeni prema popisu stanovništva Makedonije iz 2002., koji je i posljednji održan u toj zemlji (MAKSTAT - Državni zavod za statistiku Republike Makedonije - Database, 2017.).

${ }^{36}$ Podaci su navedeni prema popisu stanovništva Crne Gore iz 2011. (Monstat, Podaci na razini Crne Gore, 2017.).

${ }^{37}$ Eurostat, 2016.: 18.

${ }^{38}$ Državni zavod za statistiku Hrvatske, Procjene stanovništva Republike Hrvatske u $2015 .$.

${ }^{39}$ Republički zavod za statistiku Srbije, Procene stanovništva Republike Srbije, 2015.

${ }^{40}$ MAKSTAT, 2016.: 8.

${ }^{41}$ Monstat, 2014.: 55.

${ }^{42}$ Državni zavod za statistiku Hrvatske, Statistički ljetopis , 2016.: 113.

${ }^{43}$ Republički zavod za statistiku Srbije, Statistički godišnjak, 2017.: 25.

${ }^{44}$ MAKSTAT - Državni zavod za statistiku Republike Makedonije, Statistički godišnjak, 2017.: 59.

${ }^{45}$ Monstat, 2016.: 36.

${ }^{46}$ Državni zavod za statistiku Hrvatske, Statistički ljetopis, 2016.: 120.

${ }^{47}$ Republički zavod za statistiku Srbije, Statistički godišnjak, 2017.: 34.

${ }^{48}$ MAKSTAT, 2016.: 11.

${ }^{49}$ Monstat, 2016.: 36.
} 
statističke i druge potrebe, a između kojih tradicionalno postoje drastične socio-ekonomske razlike. U tabeli 4. su uspoređeni statistički pokazatelji ta dva faktora s odgovarajućim pokazateljima rasporeda ulaga- ča u dobrovoljne mirovinske fondove, pri čemu treba naglasiti da su izneseni ujedno i jedino dostupni službeni pokazatelji ključnih faktora utjecaja na regionalnom planu u Crnoj Gori.

Tablica 4.

Prikaz utjecaja dva socio-ekonomska faktora na lokalnoj/regionalnoj razini u Crnoj Gori ${ }^{50}$

\begin{tabular}{lccc} 
& $\begin{array}{c}\text { Sjeverna } \\
\text { regija }\end{array}$ & Središnja regija & Južna regija \\
\hline Broj stanovnika & 177800 & 292800 & 148600 \\
\hline $\begin{array}{l}\text { Broj članova dobrovoljnih mirovinskih } \\
\text { fondova }\end{array}$ & 208 & 1571 & 431 \\
\hline $\begin{array}{l}\text { Broj članova dobrovoljnih mirovinskih } \\
\text { fondova na 1 000 stanovnika }\end{array}$ & 1,17 & 5,37 & 2,9 \\
\hline $\begin{array}{l}\text { Stopa nezaposlenosti } \\
\text { Postotak visokoobrazovanih osoba }\end{array}$ & $37,3 \%$ & $12,4 \%$ & $7,8 \%$ \\
\hline
\end{tabular}

Dakle, iz tablice 4. možemo uočiti korelaciju između statističkih pokazatelja dvaju promatranih socio-ekonomskih faktora koji utječu na broj ulagača u dobrovoljne mirovinske fondove - stope nezaposlenosti i razine obrazovanja stanovništva, na jednoj strani, te broja članova dobrovoljnih mirovinskih fondova $\mathrm{u}$ tri crnogorske regije, na drugoj strani. Očekivano, značajno niže stope nezaposlenosti, te veći broj visokoobrazovanog stanovništva u južnoj i središnjoj regiji su u korelaciji s većim brojem ulagača u dobrovoljne mirovinske fondove u ovim sredinama, što govori da i u Crnoj Gori ovi socio-ekonomski faktori djeluju na relativno standardan, tj. očekivan način.

U pogledu nerazmjera u broju članova dobrovoljnih mirovinskih fondova između južne i središnje regije, ističemo da je sjedište najvećeg dobrovoljnog mirovinskog fonda u Crnoj Gori, koji okuplja $90 \%$ ukupnog broja ulagača, ali i sjedište njegovog društva za upravljanje i ostalih trgovačkih društava iz te poslovne grupe u Podgorici, koja je administrativni centar Crne Gore i pripada središnjoj regiji. Drugim riječima, nerazmjerno veći broj članova dobrovoljnih mirovinskih fondova u središnjoj regiji rezultat je posve izvjesne okolnosti da je značajan broj ovih osoba zaposlen u koncernu kojem pripada spomenuto društvo za upravljanje. No, s obzirom da se takve specifičnosti uočavaju i mogu biti od značaja na međuregionalnoj razini, unutar jedne države, ali ne i na međudržavnoj razini, uključujući i analizirane države regije, to iste nisu bile predmetom daljnjih analiza $\mathrm{u}$ ovom radu.

\section{Poredbena analiza zakonskih okvira kao sublimata političko- pravnih faktora utjecaja na uspjeh sustava dobrovoljnog mirovinskog osiguranja}

Rezultati dijela istraživanja predstavljenog u prethodnom poglavlju pokazuju da suštinske uzroke izraženog neuspjeha su-

\footnotetext{
${ }^{50}$ Izvor za podatke u tablici, osim u dijelu broja ulagača (Monstat, 2016.). Izvor za podatak o regionalnom rasporedu ulagača su dobrovoljni mirovinski fondovi u Crnoj Gori, na zahtjev Komisije za vrijednosne papire, a po upitu autora.
} 
stava dobrovoljnog mirovinskog osiguranja u Crnoj Gori treba tražiti izvan ključnih socio-ekonomskih faktora utjecaja, jer su njihovi pokazatelji u promatranim državama prilično ujednačeni. U tom smislu, u uvodnom dijelu rada postavljena je hipoteza prema kojoj su pravno-politički faktori ti čiji je utjecaj bio presudan u konkretnom slučaju. Pri tome su autori primarno imali u vidu zakonski okvir kao sublimaciju pravno-političkih faktora i posebno različite poticaje financijske prirode koji se redovno jamče nacionalnim zakonodavstvima. Naime, na širem političkom planu, potrebno je imati u vidu da Crna Gora i s njom uspoređene države bivše Jugoslavije predstavljaju političke, ekonomske i pravne sustave koji su najveći dio prethodnog stoljeća bili integrirani u zajednički državni prostor. Čak i danas, nekoliko desetljeća nakon nestanka bivše Jugoslavije, riječ je o državama koje su postale dio Europske unije ili su kao zemlje kandidati već duže u podudarnim procesima intenzivnog usklađivanja svojih političkih, ekonomskih i pravnih sustava sa strogim standardima, tj. uvjetima za članstvo. Crna Gora je i u tom pogledu blizu »regionalne statističke sredine« jer će izvjesno biti sljedeća država koja će poslije Hrvatske postati članicom Europske unije, a istovremeno je u pogledu napretka $\mathrm{u}$ integracijama znatno ispred ostala dva regionalna kandidata za članstvo, Srbije i Makedonije. Štoviše, pored navedenog, u kontekstu političko-pravnih faktora utjecaja vrijedi naglasiti i to da je, prema dostupnim informacijama, uvođenje dobrovoljnih mirovinskih fondova u sva četiri slučaja praćeno snažnom podrškom države, edukativnim i marketinškim kampanjama s jasnim ciljem promoviranja trećeg stupa mirovinskog osiguranja na institucionalnoj i široj društvenoj razini. Zato je, smatramo, opravdan pristup po kojem su istraživanje i poredbena analiza pokazatelja političkopravnih faktora utjecaja u predmetnom istraživanju ograničeni na zakonske okvire dobrovoljnih mirovinskih fondova u navedenim državama.

Naposlijetku, iako istraživanja predmetnog fenomena primarno ukazuju na socio-ekonomske faktore utjecaja kao ključne, ${ }^{51}$ autori svakako ne zanemaruju ni mogući utjecaj socio-kulturnog okvira i ukupnog društveno-povijesnog nasljeđa na sklonost stanovništva prema različitim oblicima štednje, uključujući i dobrovoljno mirovinsko osiguranje. Štoviše, rijetke studije ukazuju da značajne razlike između zemalja, odnosno društava u tom pogledu (poput razlika na planu religioznosti, poslovne kulture stanovništva, naslijeđenog (ne)povjerenja u javni i financijski sektor) mogu utjecati na razinu učešća $u$ različitim oblicima privatne štednje (Castro Campos et al., 2013.). Ipak, već istaknute sličnosti, tj. politički, ekonomski i širi društveni procesi kroz koje su u prethodnom i ovom stoljeću prolazile i danas prolaze države bivše Jugoslavije snažno govore u prilog tome da između Crne Gore na jednoj strani, te Hrvatske, Srbije i Makedonije na drugoj strani, makar na spomenutom planu, ne postoje takva odstupanja kojima bi se mogla opravdati drastična razlika u pogledu razvijenosti sustava dobrovoljnog mirovinskog osiguranja. ${ }^{52}$ Odatle daljnji predmet ovog istraživanja nisu bili socio-kulturni i psihološki

\footnotetext{
${ }^{51}$ Riječ je o istraživanjima već spomenutim u prethodnom dijelu rada, koji se bavi poredbenom analizom socioekonomskih faktora (Sane i Thomas, 2015.; Adzawla et al., 2015..; Pfarr i Schneider, 2013.; Collins-Sowah et al., 2013.; Fuentes Corripio, 2010.; Castel, 2008.).

${ }^{52}$ Primjerice, u pogledu povjeranja u financijski sektor, svaku od četiri promatrane zemlje karektizira snažna ekspanzija tržišta kapitala do globalne financijske i ekonomske krize, ali i snažan pad tržišta i povjerenja građana u isto nakon što se kriza krajem prethodnog desetljeća snažno prelila na regiju.
} 
faktori koji mogu utjecati na ponašanje pojedinca u različitim životnim situacijama.

Imajući prethodno istaknuto $\mathrm{u}$ vidu, autori su u daljnjem tijeku istraživanja pristupili detaljnoj analizi zakonskih okvira dobrovoljnih mirovinskih fondova u Crnoj Gori, Hrvatskoj, Srbiji i Makedoniji, s naglaskom na usporedbu zajamčenih financijskih poticaja i drugih ključnih regulatornih rješenja danih u odgovarajućim zakonima ovih država. Sažet prikaz tih rezultata dan je u tablici 5., a nešto detaljnije obrazloženje u tekstu ispod.

$\mathrm{Na}$ drugoj strani, iako se rad primarno bavi analizom podataka koji se tiču trećeg stupa mirovinskog osiguranja u navedenim državama treba naglasiti da, za razliku od Crne Gore i Srbije, u Hrvatskoj i Makedoniji postoji i drugi stup mirovinskog osiguranja - obavezno privatno osiguranje. No, okolnost da, za razliku od Crne Gore, u Hrvatskoj i Makedoniji postoji i drugi stup mirovinskog osiguranja objektivno bi trebala utjecati na smanjenu potrebu i interes za ulaganje $\mathrm{u}$ dobrovoljne mirovinske fondove u Hrvatskoj i Makedoniji, čime već uočene razlike u odnosu na Crnu Goru još više dolaze do izražaja.

Tablica 5.

Usporedni prikaz ključnih zakonskih rješenja

\begin{tabular}{|c|c|c|c|c|}
\hline Kriterij usporedbe & Hrvatska ${ }^{53}$ & Srbija ${ }^{54}$ & Makedonija ${ }^{55}$ & Crna Gora ${ }^{56}$ \\
\hline $\begin{array}{l}\text { Upravljanje fondom od strane po- } \\
\text { sebnog trgovačkog društva }\end{array}$ & $\begin{array}{c}\mathrm{Da} \\
\text { (čl. 9) }\end{array}$ & $\begin{array}{c}\mathrm{Da} \\
\text { (čl. } 4)\end{array}$ & $\begin{array}{c}\mathrm{Da} \\
\text { (čl. 6) }\end{array}$ & $\begin{array}{c}\mathrm{Da} \\
\text { (čl. 4) }\end{array}$ \\
\hline $\begin{array}{l}\text { Dnevna kontrola od strane regula- } \\
\text { tora i depozitne banke }\end{array}$ & $\begin{array}{c}\mathrm{Da} \\
\text { (čl. } 273 \text { i 247) }\end{array}$ & $\begin{array}{c}\mathrm{Da} \\
\text { (čl. } 67 \mathrm{i} 64)\end{array}$ & $\begin{array}{c}\mathrm{Da} \\
\text { (čl. } 4 \text { i 150) }\end{array}$ & $\begin{array}{c}\mathrm{Da} \\
\text { (čl. } 55 \mathrm{i} 41)\end{array}$ \\
\hline $\begin{array}{l}\text { Uvjetovanost članstva u fondu mi- } \\
\text { nimalnim ulogom }\end{array}$ & $\mathrm{Ne}$ & $\mathrm{Ne}$ & $\mathrm{Ne}$ & $\mathrm{Ne}$ \\
\hline $\begin{array}{l}\text { Obveza članova da plaćaju nakna- } \\
\text { du za upravljanje }\end{array}$ & $\begin{array}{c}\mathrm{Da} \\
\text { (čl. 72) }\end{array}$ & $\begin{array}{c}\mathrm{Da} \\
\text { (čl. 23) }\end{array}$ & $\begin{array}{c}\mathrm{Da} \\
\text { (čl. 17) }\end{array}$ & $\begin{array}{c}\mathrm{Da} \\
\text { (čl. 36) }\end{array}$ \\
\hline $\begin{array}{l}\text { Restriktivna politika ulaganja sred- } \\
\text { stava fonda }\end{array}$ & $\begin{array}{c}\mathrm{Da} \\
\text { (čl. 154-166) } \\
\end{array}$ & $\begin{array}{c}\mathrm{Da} \\
\text { (čl. 31-34) } \\
\end{array}$ & $\begin{array}{c}\mathrm{Da} \\
\text { (čl. 130-142) }\end{array}$ & $\begin{array}{c}\mathrm{Da} \\
\text { (čl. } 38 \text { i 39) } \\
\end{array}$ \\
\hline $\begin{array}{l}\text { Sredstva uplaćena u fond prikuplja- } \\
\text { ju se na posebnom individualnom } \\
\text { računu }\end{array}$ & $\begin{array}{c}\mathrm{Da} \\
\text { (čl. 105) }\end{array}$ & $\begin{array}{c}\mathrm{Da} \\
\text { (čl. } 43 \text { ) }\end{array}$ & $\begin{array}{c}\mathrm{Da} \\
\text { (čl. 122) }\end{array}$ & $\begin{array}{l}\mathrm{Da} \\
\text { (čl. 34) }\end{array}$ \\
\hline $\begin{array}{l}\text { Jamstvo isplata / unaprijed utvrđe- } \\
\text { na naknada članovima }\end{array}$ & $\mathrm{Ne}^{57}$ & $\mathrm{Ne}$ & $\mathrm{Ne}$ & $\mathrm{Ne}$ \\
\hline $\begin{array}{l}\text { Mogućnost transfera sredstava iz } \\
\text { jednog u drugi fond }\end{array}$ & $\mathrm{Da}^{58}$ & $\begin{array}{c}\mathrm{Da} \\
\text { (čl. 44) }\end{array}$ & $\begin{array}{c}\mathrm{Da} \\
\text { (čl. 96) }\end{array}$ & $\begin{array}{c}\mathrm{Da} \\
\mathrm{u}(\mathrm{čl} .32)\end{array}$ \\
\hline
\end{tabular}

${ }^{53}$ Zakon o dobrovoljnim mirovinskim fondovima, Narodne novine,19/2014.

${ }^{54}$ Zakon o dobrovoljnim penzijskim fondovima i penzijskim planovima, Službeni glasnik Republike Srbije, $85 / 2005$. i $31 / 2011$.

${ }^{55}$ Zakon o dobrovoljnom kapitalno finansiranom penzijskom osiguranju, Službeni vesnik Republike Makedonije, 7/2008., 124/2010., 17/2011. i 13/2013.

${ }_{56}$ Zakon o dobrovoljnim penzionim fondovima Crne Gore, Službeni list Republike Crne Gore, 78/2006., 14/2007. i Službeni list Crne Gore, 73/2010., 40/2011. 


\begin{tabular}{|c|c|c|c|c|}
\hline Kriterij usporedbe & Hrvatska ${ }^{53}$ & Srbija ${ }^{54}$ & Makedonija ${ }^{55}$ & Crna Gora ${ }^{56}$ \\
\hline $\begin{array}{l}\text { Donja starosna granica za stjeca- } \\
\text { nje prava na isplatu sredstava iz } \\
\text { fonda }\end{array}$ & $\begin{array}{l}\text { Da } \\
\text { Navršenih } 50 \\
\text { godina } \\
\text { (čl. 3) }\end{array}$ & $\begin{array}{l}\text { Da } \\
\text { Navršenih } 58 \\
\text { godina } \\
\text { (čl. 62) }\end{array}$ & $\begin{array}{c}\text { Da } \\
10 \text { godina prije } \\
\text { stjecanja uvjeta } \\
\text { za starosnu } \\
\text { mirovinu } \\
\text { (čl. 143) }\end{array}$ & $\begin{array}{l}\text { Da } \\
\text { Navršenih } 50 \\
\text { godina } \\
\text { (čl. 33) }\end{array}$ \\
\hline Financijski stimulans za ulaganje & $\begin{array}{c}\mathrm{Da} \\
\text { (čl. 135) }\end{array}$ & $\begin{array}{c}\mathrm{Da} \\
\text { (čl. 14b) }\end{array}$ & $\begin{array}{l}\mathrm{Da} \\
\text { (čl. 158) }\end{array}$ & $\mathrm{Ne}$ \\
\hline $\begin{array}{l}\text { Mogućnost formiranja zatvorenih } \\
\text { fondova u okviru trećeg stupa mi- } \\
\text { rovinskog osiguranja (kolektivna } \\
\text { mirovinska shema) }\end{array}$ & $\begin{array}{l}\mathrm{Da} \\
\text { (čl. 120) }\end{array}$ & $\begin{array}{l}\mathrm{Da} \\
\text { (čl. 57) }\end{array}$ & $\begin{array}{l}\mathrm{Da} \\
\text { (čl. 84) }\end{array}$ & $\begin{array}{l}\mathrm{Da} \\
\text { (čl. 26) }\end{array}$ \\
\hline $\begin{array}{l}\text { Poticaji kod individualnog ulaganja } \\
\text { u dobrovoljni mirovinski fond }\end{array}$ & $\begin{array}{c}\text { Da } \\
\text { (čl. 135) } \\
\text { Godišnja } \\
\text { subvencija od } \\
15 \% \text { na ulo- } \\
\text { ženi iznos do } \\
\text { uloženih } 675 \\
\text { eura, nakon } \\
\text { čega se dalj- } \\
\text { nje ulaganje } \\
\text { ne subvenci- } \\
\text { onira } \\
\end{array}$ & $\begin{array}{c}\text { Da } \\
\text { (čl. 21a) }{ }^{61} \\
\text { Godišnji poticaj } \\
\text { u smislu oslobo- } \\
\text { đenja od poreza } \\
\text { na zaradu člana } \\
\text { fonda u iznosu } \\
\text { do } 549 \text { eura }\end{array}$ & $\begin{array}{c}\text { Da } \\
\text { (čl. 158) } \\
\text { Godišnji poticaj } \\
\text { do iznosa od } \\
\text { četiri prosječne } \\
\text { bruto zarade } \\
\text { u prethodnoj } \\
\text { godini putem } \\
\text { vraćanja plaće- } \\
\text { nog poreza na } \\
\text { dohodak } \\
\text { (2 136 eura) } \\
\end{array}$ & $\mathrm{Ne}$ \\
\hline $\begin{array}{l}\text { Poticaji poslodavcima za ulaganje } \\
\text { kod kolektivnih mirovinskih shema }\end{array}$ & 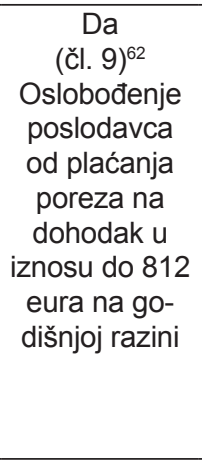 & $\begin{array}{c}\text { Da } \\
\text { (čl. 14b) } \\
\text { Godišnje oslo- } \\
\text { bođenje poslo- } \\
\text { davca od plaća- } \\
\text { nja doprinosa } \\
\text { na zaradu zapo- } \\
\text { slenika - člana } \\
\text { zatvorenog } \\
\text { fonda u iznosu } \\
\text { do } 549 \text { Eura }\end{array}$ & $\begin{array}{c}\text { Da } \\
\text { (čl. 158) } \\
\text { Godišnji poticaj } \\
\text { do iznosa od } \\
\text { četiri prosječne } \\
\text { bruto zarade } \\
\text { u prethodnoj } \\
\text { godini u vidu } \\
\text { oslobođenja } \\
\text { poslodavca od } \\
\text { poreza i dopri- } \\
\text { nosa } \\
\text { (2 136 eura) }\end{array}$ & $\mathrm{Ne}$ \\
\hline
\end{tabular}

${ }^{57} \mathrm{Na}$ području Republike Hrvatske ne može se nuditi mirovinski program zatvorenog fonda s definiranim primanjima, osim za potrebe pokrovitelja iz druge države članice. Čl. 266 Zakona o dobrovoljnim mirovinskim fondovima.

${ }^{58}$ Ograničenje se može postaviti u slučaju zatvorenih fondova dok traju odnosi iz čl. 120. Zakona o dobrovoljnim mirovinskim fondovima.

${ }^{59}$ Pravilnik o uvjetima za ostvarivanje prava na mirovinu temeljem dobrovoljnog mirovinskog osiguranja, registru članova te obustavi uplata i isplata iz dobrovoljnog mirovinskog fonda, Narodne novine, 98/2014.

${ }^{60}$ Zakon o porezu na dohodak građana, Službeni glasnik Republike Srbije, 24/2001., 80/2002. i 7/2017.

${ }^{61}$ Zakon o porezu na dohodak građana, Službeni glasnik Republike Srbije, 24/2001., 80/2002. i 7/2017.

${ }^{62}$ Zakon o porezu na dohodak, Narodne novine, 115/2016.

${ }^{63}$ Zakon o porezu na dohodak građana, Službeni glasnik Republike Srbije, 24/2001., 80/2002. i 7/2017. 
Rezultati usporedne analize sažeti u tablici 5. ukazuju na visok stupanj podudarnosti zakonskih okvira dobrovoljnog mirovinskog osiguranja u promatranim državama regije. Stoviše, uz izuzetak u pogledu financijskih stimulansa potencijalnim ulagačima u dobrovoljne mirovinske fondove, ključna rješenja suštinski su identična. ${ }^{64}$ Tako je upravljanje ovim fondovima $u$ svakoj od promatranih zemalja povjereno specijaliziranim dioničkim društvima, a u Hrvatskoj i društvima s ograničenom odgovornošću. Pored toga, u svakim od analiziranih zakonskih okvira uspostavljen je sustav neposredne kontrole od strane nadležnog regulatornog tijela. ${ }^{65} \mathrm{U}$ tom smislu, pored normativnih, ovim tijelima dane su i brojne javne ovlasti na osnovi kojih njihovi nositelji osiguravaju da postupanje društava za upravljanje bude u skladu sa zakonom i najboljim interesima samih članova.

Još jedna zajednička karakteristika promatranih zakonskih okvira jest okolnost da nije utvrđen tzv. »prag ulaska«, tj. minimalni iznos ulaganja u dobrovoljni mirovinski fond. Na drugoj strani, međutim, članovi dobrovoljnih mirovinskih fondova u svakoj od promatranih država imaju zakonom utvrđenu obvezu plaćanja naknade za upravljanje, što je logična posljedica okolnosti da su društva za upravljanje primarno lukrativnog karaktera. Štoviše, iako modeli izračunavanja naknade nisu identični, sličnosti su i u tom dijelu značajne. Tako je jedan od osnovnih zajedničkih principa na kojima su zasnovani spomenuti sustavi obračuna naknada princip obračuna dijela naknade u postotku od vrijednosti imovine fonda, čime se dodatno potiče interes društava za upravljanje da sa sredstvima uloženim $\mathrm{u}$ fond ostvaruju pozitivne prinose.
Naredna podudarnost analiziranih zakonskih okvira odnosi se na snažno promoviranje i nametanje društvima za upravljanje restriktivne investicijske politike čiji primarni cilj nije maksimalizacija profita, već likvidnost imovine fonda i siguran povrat investiranih sredstava. Naravno, sve u svrhu zaštite i unaprjeđenja javnog interesa čije ostvarenje je prvobitni raison d'être dobrovoljnih mirovinskih fondova i korespondirajućih zakonodavstava. Stoga je zajednička osobina društava za upravljanje u promatranim državama $\mathrm{i}$ to da, bez obzira što su primarno lukrativnog karaktera, imaju konzervativniju investicijsku politiku od njima vjerojatno najsličnijeg institucionalnog investitora na tržištima kapitala - investicijskih fondova. Sljedeća univerzalna karakteristika promatranih sustava dobrovoljnog mirovinskog osiguranja jest da isti nisu zasnovani na konceptu zajamčenih, tj. unaprijed određenih iznosa naknada ulagačima po stjecanju prava na isplatu sredstava iz fonda, već naknade zavise od visine uloženih sredstava i rezultata investicijske politike fondova. Nadalje, u svakoj od četiri države postoji zakonski standard prema kojem je moguć prelazak članova, tj. prijenos sredstava iz jednog u drugi dobrovoljni mirovinski fond, ali ne i isplata sredstava ulagačima dok ne navrše određeni broj godina. Štoviše, kako je i naznačeno u tablici 5., visok stupanj podudarnosti postoji i u pogledu zakonskih rješenja kojima se određuje sama starosna granica za stjecanje prava na isplatu naknada iz imovine fonda. Pri tome, u svrhu ovog istraživanja posebno vrijedi imati u vidu da je, uz Hrvatsku, upravo Crna Gora ta čija su zakonska rješenja u ovom dijelu najpovoljnija po ulagače.

${ }^{64} \mathrm{U}$ tablici 5. navedeni su članci izvornih zakonskih tekstova kojima su analizirana regulatorna rješenja ustanovljena u promatranim državama, tako da iste nazanake nisu ponavljane u tekstu.

${ }^{65}$ U Crnoj Gori je to Komisija za vrijednosne papire, u Hrvatskoj Agencija za nadzor financijskih usluga (HANFA), u Srbiji Narodna banka, a u Makedoniji Agencija za nadzor kapitalno financiranog mirovinskog osiguranja. 
Dakle, na osnovi rezultata usporedne analize njihovih bitnih karakteristika, dolazimo do zaključka da se jedina očigledna i značajna razlika između crnogorskog i ostalih analiziranih zakonskih okvira dobrovoljnog mirovinskog osiguranja tiče upravo financijskih poticaja ulagačima. Preciznije, u Crnoj Gori financijski poticaji ne postoje. Na drugoj strani, uz razlike u njihovoj visini i načinu dodjele, što je detaljnije prikazano u tablici 5., u Hrvatskoj, Srbiji i Makedoniji egzistiraju u formi poreznih olakšica ili državnih kontribucija kako individualnim ulagačima, tako i poslodavcima kod kolektivnih shema. Takav nalaz predstavlja jedan od bitnih temelja za potvrdu u uvodnom dijelu rada postavljenih hipoteza o uzrocima neuspjeha trećeg stupa mirovinskog osiguranja u Crnoj Gori i snažnom utjecaju koji financijski poticaji uopće imaju za uspjeh nacionalnog sustava dobrovoljnog mirovinskog osiguranja.

Naposlijetku, u kontekstu analize značaja financijskih poticaja, pored iznesenog, vidljive i potencijalno indikativne mogle bi biti i sljedeće činjenice iz tablice 5. Naime, maksimalno dozvoljeni iznosi financijskih poticaja poslodavcima i individualnim ulagačima (članovima) značajno su u ovom trenutku viši u Makedoniji u odnosu na Hrvatsku i Srbiju. Kada se u kontekstu tog podatka promatraju podatci iz tablice 2., koji ukazuju na to da je od promatranih država upravo u slučaju Makedonije najviši postotak koji imovina dobrovoljnih mirovinskih fondova predstavlja u odnosu na bruto društveni proizvod države, to bi se s pravom moglo smatrati još jednim pokazateljem u prilog percipiranog značaja financijskih poticaja na planu motivacije potencijalnih i postojećih članova dobrovoljnih mirovinskih fondova.

\section{ZAKLJUČNA RAZMATRANJA}

Već je istaknuto u uvodnom dijelu da su prilikom koncipiranja istraživanja izloženog u radu autori postavili dva cilja. Dokazati kako nestimulativan zakonski okvir i posebno izostanak zakonom zajamčenih financijskih poticaja predstavlja primarni uzrok neuspjeha dobrovoljnih mirovinskih fondova u Crnoj Gori, te da se na konkretnom primjeru potvrdi kako ovi stimulansi predstavljaju jedan od bitnih faktora utjecaja na uspjeh nacionalnih sustava dobrovoljnog mirovinskog osiguranja. Mada je i ta okolnost već istaknuta, značajno je i ovdje istaknuti kako je prostor za samo istraživanje i znanstvenu relevantnost njegovih rezultata osigurao specifičan, ako ne i jedinstven splet dviju okolnosti. Prva je da Crna Gora predstavlja vrlo rijedak primjer države u kojoj cjelovit i integriran sustav dobrovoljnog mirovinskog osiguranja postoji i funkcionira bez ikakvih zakonskih poticaja ulagačima. Druga, koja je u radu i demonstrirana, da postoji visok stupanj podudarnosti u pogledu učinka ostalih ključnih faktora utjecaja na uspjeh dobrovoljnih mirovinskih fondova u Crnoj Gori i zemljama regije koje su bile predmetom poredbene analize.

Dakle, autori su usporednom analizom statističkih pokazatelja ključnih socio-ekonomskih faktora utjecaja na uspjeh dobrovoljnih mirovinskih fondova utvrdili kako ti pokazatelji u Crnoj Gori ne odstupaju značajnije od onih u Hrvatskoj, Srbiji ili Makedoniji. Nakon toga, u kontekstu već elaboriranih okolnosti da je riječ o državama koje povijesno i trenutno imaju značajan stupanj podudarnosti na planu ključnih pravaca društvenog razvoja, uslijed čega predmet analize nisu bile eventualne razlike u pogledu socio-kulturnog okvira i šireg društveno-povijesnog naslijeđa, daljnje istraživanje usmjereno je na izdvajanje 
i usporednu analizu bitnih karakteristika zakonskih okvira trećeg stupa mirovinskog osiguranja spomenutih država. Slično prethodnoj, ova je analiza pokazala visok stupanj podudarnosti, uz izuzetak u pogledu financijskih poticaja članovima dobrovoljnih mirovinskih fondova i njihovim poslodavcima. Konkretno, dok u Srbiji i Makedoniji postoje u vidu poreznih olakšica, a u Hrvatskoj i u vidu subvencija, tj. godišnjih premija individualnim ulagačima, za razliku od ovih država, utvrđeno je da financijski poticaji u Crnoj Gori uopće ne postoje. Time je uvelike potvrđeno kako je nestimulativan zakonski okvir prouzrokovao neuspjeh trećeg stupa mirovinskog osiguranja u Crnoj Gori. Pored toga, izoliranjem u granicama postavljenog metodološkog okvira snažnog negativnog efekta izostanka zakonom jamčenih financijskih poticaja na razvoj sustava dobrovoljnog mirovinskog osiguranja u Crnoj Gori, istraživanjem je ostvaren i drugi postavljeni cilj. Demonstrirano je na konkretnom primjeru da financijski stimulansi predstavljaju snažan faktor utjecaja na uspjeh nacionalnih sustava dobrovoljnog mirovinskog osiguranja.

Konačno, imajući u vidu još uvijek prisutna nesuglasja i dvojbe u pogledu značaja financijskih stimulansa za razvoj dobrovoljnog mirovinskog osiguranja, rezultati ovog istraživanja mogu predstavljati vrijedan orijentir za nacionalne zakonodavce i druge donositelje odluka u sve češćim procesima revizije i regulatorne nadgradnje nacionalnih mirovinskih sustava.

Kada je Crna Gora u pitanju, imajući u vidu spomenuta negativna iskustva crnogorskih i građana regije s tržištem kapitala u bliskoj prošlosti, te okolnost da je treći stup mirovinskog osiguranja još uvijek u neku ruku novitet u regiji, kako bi se postigao njihov puni efekt, eventualno uvođenje financijskih poticaja trebalo bi biti praćeno dobro osmišljenom kampanjom usmjerenom na daljnju edukaciju potencijalnih članova, te jačanje povjerenja u financijsko tržište. S tim u vezi, iako u radu nije pravljena poredbena analiza dva dominantna obrasca financijskih poticaja, poreznih olakšica i državnih subvencija, čini se kako bi na aktualnoj razini razvoja crnogorskog ekonomskog i uopće društvenog sustava potencijalno učinkovitije bilo pratiti hrvatski primjer i uvesti subvencije za individualne ulagače. Naime, bjelodano je da u Crnoj Gori još uvijek postoji visok stupanj zakonite i nezakonite porezne evazije, te da je riječ o problemu čije rješavanje, između ostalog, zahtijeva i vrijeme za promjenu svijesti, tj. odnosa poreznih obveznika prema zakonskim obvezama. Odatle i značajan broj pojedinaca, a time i potencijalnih ulagača u dobrovoljne mirovinske fondove ne doživljava porezne olakšice značajnim i poticajnim u mjeri u kojoj je to slučaj u većini društava koja kolokvijalno nazivamo zapadnim demokracijama. Na drugoj strani, pak, kultura oslanjanja na različite vidove državne pomoći naslijeđena iz doba socijalizma, iako potiskivana intenzivnim procesom integracije s Europskom unijom, još uvijek je vrlo prisutna u Crnoj Gori, što je argument više u prilog iznesenog stava.

\section{LITERATURA}

Adzawla, W., Baanni, S. A., \& Wontumi, R. F. (2015). Factors influencing informal sector workers' contribution to pension scheme in the Tamale Metropolis of Ghana. Journal of Asian Business Strategy, 5(2), 37-45.

Agencija za superviziju kapitalno finansiranog penzijskog osiguranja. (2015). Godišnji statistički izvještaj za 2015. godinu. Dostupno na http://mapas.mk/wp-content/uploads/2016/02/ Godisen-statisticki-izvestaj_2015_MK.pdf

Blake, D. (2006). Pension finance. Chichester: John Wiley \& Sons. 
Bernheim, B. D. (2001). Taxation and saving. In A. J. Auerbach \& M. S. Feldstein (Eds), Handbook of Public Economies (Vol. 3) (pp. 113-138). Amsterdam: Elsevier.

Börsch-Supan, A., Reil-Held, A., \& Schunk, D. (2007). The savings behaviour of German households - First experiences with state promoted private pensions. MEA Working Paper, Nr. 136-2007. Mannheim: Mannheim Research Institute for the Economics of Aging. Dostupno na https://core.ac.uk/download/ pdf/6349719.pdf

Bornarova, S., Bogoevska, N., \& Trbojevik, S. (2013). Pension system reforms in the Republic of Macedonia: Expected benefits and challenges. Academic Journal of Interdisciplinary Studies, 2(9), 393-399. https://doi. org/10.5901/ajis.2013.v2n9p393

Bosi, P., \& Guerra, M. C. (2002). The role of tax incentives in voluntary pension schemes in Italy: What can other countries learn from this?. Fourth International Forum of the Collaborating Projects on Ageing Issues, Tokyo, February 18-21, 2002. Dostupno na http:// merlino.unimo.it/campusone/web_dep/materiali_discussione/0402.pdf

Castel, P. (2008). Voluntary defined benefit pension system willingness to participate: The case of Vietnam. SSRN Electronic Journal. Dostupno na https://ssrn.com/abstract=1379607

De Castro Campos, M., Kool, C., \& Muysken, J. (2013). Cross-country private saving heterogeneity and culture. De Economist, 161(2), 101-120. https://doi.org/10.1007/s10645-0139204-6

Chen, D. H. J., \& Beetsma, R. M. W. J. (2015). Mandatory participation in occupational pension schemes in the Netherlands and other countries: An update. Netspar Research Paper Series. Dostupno na https:/www.netspar.nl/ en/publication/mandatory-participation-inoccupational-pension-schemes-in-the-netherlands-and-other-countries-an-update/

Collins-Sowah, P. A., Kuwornu, J. K. M., \& Tsegai D. (2013). Willingness to participate in micro pension schemes: Evidence from the informal sector in Ghana. Journal of Economics and International Finance, 5(1), 21-34. https://doi. org/10.5897/JEIF12.097
Državni zavod za statistiku Republike Hrvatske. (2016a). Statistički ljetopis. Dostupno na http:/www.dzs.hr/Hrv_Eng/ljetopis/2016/ sljh2016.pdf

Državni zavod za statistiku Republike Hrvatske. (2016b). Popis stanovništva iz 2011. Dostupno na http://www.dzs.hr/Hrv_Eng/publication/2016/SI-1582.pdf

Državni zavod za statistiku Republike Hrvatske. (2016c). Procjene stanovništva Republike Hrvatske u 2015. [datoteka s podacima]. Dostupno na http://www.dzs.hr/Hrv_Eng/publication/2016/07-01-04_01_2016.htm

Državni zavod za statistiku Republike Hrvatske. (2017). Procjena stanovništva prema dobnim skupinama i spolu, po županijama, 31.12. [datoteka s podacima]. Dostupno na http://www.dzs.hr/App/PXWeb/PXWebHrv/ Table.aspx?layout=tableViewLayout $1 \& p \mathrm{x}$ tableid=SP22_2.px\&px_path $=$ Stanovni $\%$ c5 $5 \%$ a1tvo Procjene \%20stanovni\%c5\%a1tva\& $\mathrm{px}$ language $=\mathrm{hr} \& \mathrm{px} \_\mathrm{db}=$ Stanovni $\% \mathrm{c} 5 \%$ a 1 tvo\&rxid=25759ed2-ae21-45a5-a8bc$8 \mathrm{c} 83 \mathrm{e} 950 \mathrm{bcd} 6$

Državni zavod za statistiku Republike Makedonije. (2016). 25 godina nezavisne Makedonije. Dostupno na http://www.stat.gov.mk/ Publikacii/25godiniRM.pdf

Državni zavod za statistiku Republike Makedonije. (2017a). Database 2017. [datoteka s podacima]. Dostupno na http://makstat.stat.gov. mk/PXWeb/pxweb/en/

Državni zavod za statistiku Republike Makedonije. (2017b). Proceni na naselenie [datoteka s podacima]. Dostupno na http://makstat.stat. gov.mk/PXWeb/pxweb/mk/MakStat/

Državni zavod za statistiku Republike Makedonije. (2017c). Statistički godišnjak [datoteka s podacima]. Dostupno na http://www.stat.gov. $\mathrm{mk} /$ PrikaziPublikacija_1.aspx?rbr=674

European Parliament - Directorate General for Internal Policies. (2014). Pension schemes. Dostupno na http://www.europarl.europa.eu/ RegData/etudes/STUD/2014/536281/ IPOL_ STU(2014)536281_EN.pdf

Eurostat. (2016). Key figures on Europe 2016 edition [datoteka s podacima]. Dostupno na http://ec.europa.eu/eurostat/documents/3217494/7827738/KS-EI-16-001EN-N.pdf/bbb5af7e-2b21-45d6-8358-9e$130 \mathrm{c} 8668 \mathrm{ab}$ 
Eurostat. (2017a). Gross domestic product at market prices [datoteka s podacima]. Dostupno na http://ec.europa.eu/eurostat/tgm/refreshTableAction.do?tab $=$ table $\&$ plugin $=1 \&$ pcode $=$ tec 00 001\&language=en;

Eurostat. (2017b). Purchasing power parities (PPPS) [datoteka s podacima]. Dostupno na http://appsso.eurostat.ec.europa.eu/nui/ show. do?dataset $=$ prc_ppp_ind\&lang=en

Fuentes Corripio, E. (2010). Creating incentives for voluntary contributions to pension funds by independent workers: An informal evaluation based on the case of Chile. BBva Research Working Papers, 10/12. Dostupno na https:/www.bbvaresearch.com/KETD/fbin/ mult/WP_1012_tcm348-221423.pdf

Guardiancich, I. (2010). Pensions and social inclusion in three ex-Yugoslav countries: Slovenia, Croatia and Serbia. Acta Oeconomica, 60(2), 161-195. https://doi.org/10.1556/aoecon.60.2010.2.3

Hrvatska agencija za nadzor financijskih usluga. (2015). Godišnje izvješće 2015. godine. Dostupno na http://www.hanfa.hr/getfile/44255/ Godisnje\%20izvjesce\%202015_web.pdf

Jansson, B. S. (2005). Tax Expenditures (United States). In J. M. Herrick \& P. H. Stuart (Eds.), Encyclopedia of Social Welfare History in North America (pp. 405-407) Thousand Oaks, CA: Sage.

Komisija za hartije od vrijednosti Crne Gore. (2015). Godišnji izvještaj o radu za 2015. godinu. Dostupno na http://www.scmn.me/fajlovi/GodisnjiIzvjestaj2015.pdf

Majcen, B., \& Verbič M. (2009). The Slovenian pension system in the context of upcoming demographic developments. In R. Holzmann, L. MacKellar \& J. Repanšek (Eds.), Pension Reform in Southeastern Europe: Linking to Labor and Financial Market Reforms (pp. 7388). Washington, D.C.: World Bank; Ljubljana: Centre for Excellence in Finance.

Narodna banka Srbije. (2015). Izvještaj o poslovanju dobrovoljnih mirovinskih fondova četvrto tromesečje 2015. godine. Dostupno na https://www.nbs.rs/internet/latinica/62/62_2/ dpf_04_15.pdf

Paiella, M., \& Tiseno, A. (2014). Evaluating the impact on saving of tax-favored retirement plans. Journal of Pension Economics and Finance, 13(1), 62-87. https://doi.org/10.1017/ S147474721300019X

Pfarr, C., \& Schneider, U. (2013). Choosing between subsidized or unsubsidized private pension schemes: Evidence from German panel data. Journal of Pension Economics and Finance, 12(1), 62-91. https://doi.org/10.1017/ S1474747212000170

Republički zavod za statistiku Makedonije. (2016). Monthly Statistical Bulletin no 12. Dostupno na http://www.stat.gov.mk/Publikacii/1.2.16.12_en.pdf

Republički zavod za statistiku Srbije (2011). [datoteka s podacima]. Dostupno na http://www. stat.gov.rs/WebSite/Public/ReportResultView. aspx?rptKey=indId $\% 3 \mathrm{~d} 18030102$ IND01\%26 $2 \% 3 \mathrm{~d} 201500 \% 26102 \% 3 \mathrm{dRS} \% 2648 \% 3 \mathrm{~d} 0 \% 2$ $66 \% 3 \mathrm{~d} 1 \% 2 \mathrm{c} 3 \% 2623 \% 3 \mathrm{~d} 0 \% 26$ sAreaId $\% 3 \mathrm{~d} 1$ 8030102\%26dType\%3dIdentificatorAndNam e\%261Type\%3dSerbianCyrillic

Republički zavod za statistiku Srbije. (2015). Procene stanovništva Republike Srbije, 2015. [datoteka s podacima]. Dostupno na http://www. stat.gov.rs/WebSite/Public/PublicationView.as $\mathrm{px}$ ?pKey $=41 \& \mathrm{pLevel}=1 \&$ pubType $=2 \&$ pubK ey $=3646$

Republički zavod za statistiku Srbije. (2016). Statistički kalendar Republike Srbije. Dostupno na http://pod2.stat.gov.rs/ObjavljenePublikacije/G2016/pdf/G20162018.pdf

Republički zavod za statistiku Srbije. (2017). Statistički godišnjak. Dostupno na http://pod2. stat.gov.rs/ObjavljenePublikacije/G2017/pdf/ G20172021.pdf

Rocha, R., \& Vittas, D. (2002). The Hungarian pension reform: A preliminary assessment of the first years of implementation. In M. Feldstein \& H. Siebert (Eds.), Social Security Pension Reform in Europe (pp. 365-400). Chicago: The University of Chicago Press.

Sane, R., \& Thomas, S. (2015). In search of inclusion: Informal sector participation in a voluntary, defined contribution pension system. The Journal of Development Studies, 51(10), 1409-1424. https://doi.org/10.1080/00220388 .2014 .997220

Verbon, H. (1988). The evolution of public pension schemes. Heidelberg: Springer. 
Vlada Crne Gore. (2013). Analiza penzijskog osiguranja. Dostupno na https://www.google. com/url? sa $=t \& r c t=j \& q=\&$ esrc $=$ s\&source $=$ we $\mathrm{b} \& \mathrm{~cd}=1 \& \mathrm{cad}=\mathrm{rja} \&$ uact $=8 \& \mathrm{ved}=0 \mathrm{ahUKEwj}$ j18HR_f7UAhXJ8RQKHTq5CBIQFggnMA A\&url=http $\% 3 \mathrm{~A} \% 2 \mathrm{~F} \% 2 \mathrm{Fwww}$. gov.me $\% 2 \mathrm{FR}$ esourceManager\%2FFileDownload.aspx $\% 3 \mathrm{~F}$ rId\%3D99613\%26rType\%3D2\&usg=AFQjC NHBwdj_CtpRDbQHK29vFpUOfyFmhg

World Bank. (1994). Averting the old age crisis: Policies to protect the old and promote growth. Washington, D.C.: World Bank. https://doi. org/10.1596/0-8213-2970-7

World Bank. (2005). Old age support in the 21st century: An international perspective on pension systems and reform. Washington, D.C.: World Bank. https://doi.org/10.1596/0-82136040-X
Zavod za statistiku Crne Gore. (2014). Projekcije stanovništva Crne Gore do 2060. godine sa strukturnom analizom stanovništva Crne Gore. Dostupno na http://www.monstat.org/ userfiles/file/publikacije/Demografska\%20 analiza $\% 20 \% 20 \mathrm{za} \% 20$ sajt $\% 2028 \% 20 \% 20$ mart.pdf

Zavod za statistiku Crne Gore. (2016). Statistički godišnjak 2016. Dostupno na http://monstat. org/cg/publikacije_page.php?id=1474

Zavod za statistiku Crne Gore. (2017a). Procjene stanovništva - Podaci [datoteka s podacima]. Dostupno na http://www.monstat.org/cg/page. php?id=273\&pageid $=48$

Zavod za statistiku Crne Gore. (2017b). Podaci na nivou Crne Gore [datoteka s podacima]. Dostupno na http://monstat.org/cg/page. php?id $=534$ \&pageid $=322$ 


\title{
Summary
}

\section{DESTIMULATIVE LEGISLATIVE FRAMEWORK AS THE CAUSE OF FAILURE OF VOLUNTARY PENSION SCHEMES: A MONTENEGRIN CASE STUDY AS AN INDICATOR OF THE RELEVANCE OF FINANCIAL INCENTIVES}

\author{
Vladimir Savković \\ Nikola Dožić \\ University of Montenegro \\ Faculty of Law \\ Podgorica, Montenegro
}

This paper presents a research having two closely related aims. First, to prove that the destimulative regulatory framework, and in that context the absence of financial incentives for members in particular, is the principal cause for the failure of voluntary pension insurance in Montenegro. Second, to establish within the given methodological framework that financial incentives are one of the key success factors of voluntary pension insurance schemes. The research itself was structured so as to exploit two key circumstances. One being that Montenegro is a rare example of a country providing no financial incentives for investing in voluntary pension funds and the other being that the indicators of the remaining key success factors of voluntary pension funds - both in Montenegro and the rest of the ex-Yugoslav countries being the object of comparative analysis - are of approximately similar values. Thanks to this, in the research the authors manages to isolate a strong negative effect of the absence of regulatory incentives on the success of voluntary pension scheme in Montenegro. In doing so, they managed to confirm the primary two hypotheses about the cause for the failure of the Montenegrin system and the relevance of financial incentives for the development of voluntary pension insurance.

Key words: voluntary pension insurance, legislative framework, financial incentives, key success factors, Montenegro, ex-Yugoslav countries. 